\title{
異なる昼温および夜温がズッキーニの雌花形成に及ぼす影響
}

\author{
池浦博美 *・徳田貴彦・早田保義 \\ 明治大学農学部 214-8571 神奈川県川崎市多摩区東三田
}

\section{Effects of Different Day and Night Temperatures on Female Flower Formation in Zucchini}

\author{
Hiromi Ikeura*, Takahiko Tokuda and Yasuyoshi Hayata \\ School of Agriculture, Meiji University, Higashimita, Tama-ku, Kawasaki, Kanagawa 214-8571
}

\begin{abstract}
The effect of several day and night temperature combinations on zucchini female flower formation was investigated in a temperature-controlled climate chamber under natural sunlight. The total number of flowers increased with higher night temperatures, but there was no difference in the number of female flowers and the length of the largest leaf. The ratio of female flowers to the total number of flowers was significantly lower at day $/$ night $30^{\circ} \mathrm{C} / 30^{\circ} \mathrm{C}$ than at $30^{\circ} \mathrm{C} / 10^{\circ} \mathrm{C}$ and $30^{\circ} \mathrm{C} / 20^{\circ} \mathrm{C}$. The female flowering and fruit-setting rates were highest at $30^{\circ} \mathrm{C} / 10^{\circ} \mathrm{C}$ and $30^{\circ} \mathrm{C} / 20^{\circ} \mathrm{C}$. Higher daytime temperatures $\left(25^{\circ} \mathrm{C} / 15^{\circ} \mathrm{C}\right.$ and $35^{\circ} \mathrm{C} / 15^{\circ} \mathrm{C}$ ) increased the number of total flowers. These results indicate that female flower formation of zucchini was decreased by increasing the night temperature, and that both female flower blooming and fruit-setting were markedly inhibited at $30^{\circ} \mathrm{C} / 30^{\circ} \mathrm{C}$.
\end{abstract}

Key Words : cultivar temperature, day and night temperature, female flower differentiation キーワード：昼夜温，雌花分化，栽培温度

\section{緒 言}

ズッキーニ (Cucurbita pepo L.) は北アメリカ大陸原産の 野菜であり, ウリ科力ボチャ属に属するつるなし性の一年 草果菜である。西洋野菜の一つとして欧米などでは一般的 で人気の高い野菜であり，近年では中国や韓国などでもよ く食べられるよらになり, 現在, 我が国では和食への利用 ならびに食の欧米化に伴い需要が増加している.

ズッキー二の収穫量は着果する雌花数に大きく影響を受 けるが，その花芽着生様式は主茥の第 $8 \sim 9$ 節から雌花を 着生し始め, 第 15 節あたりから健全な雌花が着生し, 果形 の良好な果実が得られるようになる。また，ズッキーニは 各節に雌花か花粉供給花である雄花のいずれかを 1 花着生 することから，雌雄分化の割合をらまく保つことで収穫量 の増加につながると考光られる。しかしながら, 雌花の割 合が高くなりすぎても，受粉用の雄花が確保できず，ある いは雌花間の養分競合が生じて雌花の着果不良が発生しや すくなり，特に開花前 $5 \sim 2$ 日までの低日照は光合成量の 低下とともに雌花の発育不全を誘導し, 着果率が著しく低 下することが報告されており（Li ら，2005），また，ズッ キー二の雌花は受粉後 $30^{\circ} \mathrm{C}$ 以上の高温にさらされると正

2011 年 8 月 18 日 受付. 2012 年 2 月 10 日 受理.

* Corresponding author. E-mail: hikeura@isc.meiji.ac.jp
常な果実肥大が起こらず，果実は先細り果や短果といった 規格外果になることなどが知られている（田口ら，2004）. これまでウリ科の果実の着果に関する研究は多く（Haim ら，1989; 早田，1988; 早田ら，1990），ズッキーニと同科 であるキュウリでは雌花形成と外的環境要因との関係につ いて，雌花形成を引き起こす要因に温度，日長および光強 度などがあり，低温，短日および強光量で雌花形成が促進 され，特に温度を $30^{\circ} \mathrm{C}$ から $20^{\circ} \mathrm{C}$ へ下げると，長日，弱光 量条件下でも雌花形成が促進されることから，温度が雌花 形成に強く影響することが報告されている (Papadopoulou・ Grumet, 2005; Takahashi ら，1983）。一方，Wien ら（2004）は カボチャ属の装飾用カボチャ（Cucurbita pepo L.）では，高 温で雌花の形成および開花が遅延することを示唆している が，ズッキーニに拈いては，温度の違いによる雌花形成への 影響や開花と温度に関する研究は皃とんど見当たらない

そこで本研究では，ズッキー二の雌花形成における昼温 および夜温の影響を調査するために，自然光型人工気象装 置を用い，数段階での昼夜温処理を行った。 また，へチマ で雌花形成に影響しているといら報告（Omini・Hossain, 1987）のある無機成分の動態についても検討した.

\section{材料および方法}

\section{1. 供試材料, 栽培方法および温度処理}

供試品種は“ダイナー（タキイ種苗）とし，育苗ならび 
に定植培養土にはくみあい園芸育苗培土（ $\mathrm{N}: 0.15 \mathrm{~g} \cdot \mathrm{L}^{-1}$, $\mathrm{P}: 3.00 \mathrm{~g} ・ \mathrm{~L}^{-1}, \mathrm{~K}: 0.15 \mathrm{~g} ・ \mathrm{~L}^{-1}$, コープケミカル) とバー ミキュライト（昭和バーミキュライト）を 1 対 1 で混合し たものを用い，育苗のための施肥は大塚八ウス 1 および 2 号（大塚化学）を液肥標準濃度の 2 倍液 $\left(\mathrm{N}: 520 \mathrm{mg} \cdot \mathrm{L}^{-1}\right.$, $\left.\mathrm{P}: 240 \mathrm{mg} \cdot \mathrm{L}^{-1}, \mathrm{~K}: 810 \mathrm{mg} \cdot \mathrm{L}^{-1}\right)$ を, 定植後の施肥は定 植培養土にエコロング 424-100 (N : P : K = 14: $12: 14$, チッ ソ） $80 \mathrm{~g}$, 苦土石灰 $7 \mathrm{~g}$, みのり堆肥（富士見工業） $210 \mathrm{~g}$ を施用した。

夜温処理実験は，2009年 11 月 4 日〜 2010 年 1 月 14 日 にかけて明治大学生田校舎の自然光型人工気象装置 (小系 工業） 3 室で行った. 2009 年 11 月 4 日にガラス温室で育苗 土に供試種子を播種し, 発芽後口径 $12 \mathrm{~cm}$ ポリポット（高 さ $10 \mathrm{~cm})$ に移植した後, 第 7 葉展開時まで育苗した。 さ らに, 2009 年 12 月 2 日に口径 $30.5 \mathrm{~cm}$ ポリポット（鉢土 $15 \mathrm{~L}$, 高さ $30.5 \mathrm{~cm})$ 飞苗を移植し, 夜温を変動させた自然 光型人工気象装置内の各チャンバーに 10 株ずつ搬入した. な拈，ガラス温室は，最低温度 $15^{\circ} \mathrm{C} \sim$ 最高温度 $30^{\circ} \mathrm{C}$ の範 囲で, 電熱線による暖房, 自動天空拈よび手動側空の開閉 によって換気を行った。

昼温処理実験は，2009年 2 月 1 日〜 3 月 29 日にかけて 行った. 2 月 1 日に供試種子を播種し, 2 月 14 日にポリポッ 卜に移植した後, 本葉第 10 葉展開後, 2 月 27 日に夜温処 理と同様の培土の入った $30.5 \mathrm{~cm}$ ポリポットに移植し, 自 然光型人工気象装置に搬入した.

夜温処理実験における栽培設定温度および処理時間は, 全処理区の昼温を $30^{\circ} \mathrm{C}$ に固定し, 低夜温区 $10^{\circ} \mathrm{C}$, 中夜温 区 $20^{\circ} \mathrm{C}$ および高夜温区 $30^{\circ} \mathrm{C}$ の 3 処理区を設け，処理時間 は昼温を8:30〜 17:30，夜温を18:30～6:30 とした.なお， 昼温打よび夜温処理に打いて，昼温から夜温への切り替え は1時間, 夜温から昼温への切り替えは2時間かけて行った。

昼温処理実験における栽培設定温度および処理時間は, 全処理区の夜温を $15^{\circ} \mathrm{C}$ に固定し, 低昼温区 $20^{\circ} \mathrm{C}$, 中昼温 区 $25^{\circ} \mathrm{C}$ 和よび高昼温区 $35^{\circ} \mathrm{C}$ の 3 処理区を設け，処理時間 は夜温処理実験と同様にした．各処理区は 10 株とした。 な お，本実験の温度処理の範囲は，夜温処理では夏を想定し て昼温 $30^{\circ} \mathrm{C}$ とし, 夜温变動は夏を想定した $30^{\circ} \mathrm{C}$, 秋〜冬 を想定した $10^{\circ} \mathrm{C}$ ，それらの間の $20^{\circ} \mathrm{C} の 3$ 处理区とした. 昼温処理では，温室のズッキー二栽培において夜温として ほぼ最低温度である $15^{\circ} \mathrm{C}$, 昼温は一定温度の $15^{\circ} \mathrm{C}$ から真 夏を想定した $35^{\circ} \mathrm{C}$ ，それらの間の温度 $25^{\circ} \mathrm{C}$ に設定した。 また, 日長や日射量子花成に影響する可能性があるが, ズッ キーニと同科であるキュウリでは温度が強く影響すること が判明している（Grimstad・Frimanslund, 1993; Hikosaka ら, 2008）。そこで，今回の実験では短日，弱光量の時期であっ たが，同条件での温度のみの影響を観察した。

\section{2. 生育調査および無機成分分析}

生育調査は, 各処理区とも自然光型人工気象装置搬入後, 6 日間隔で行った. 調査項目は総花数, 雌花数おょび最大
葉長について行った．雌花率（総花数に対する雌花数の割 合）は雌花数 /総花数 $\times 100$ で, 雌花の開花率は，実際に 開花した雌花 /総雌花数 $\times 100$ で，着果率は受粉後 5 日後 までに成長した雌花／総䧳花数 $\times 100$ で算出した. 受粉は, 午前 $8 \sim 9$ 時の間に人工授粉を行った.

各株の無機栄養状態を調査するため, 各温度処理栽培終 了後に, 花芽を分化する成長点を含めた最上位葉から順に 上から 5 枚の葉を採取し, $80^{\circ} \mathrm{C}$ で約 1 日間通風乾燥させ, 粉末になるまでミキサーで粉砕した．試料の分解は湿式灰 化法（永原ら，1964）を用いて行い，この試料液を以下の 分析に使用した. $\mathrm{N}$ 含量は水蒸気蒸留法 (嶋田, 2003), K, $\mathrm{Ca}$ 战よび $\mathrm{Mg}$ 含量は原子吸光光度計, $\mathrm{P}$ 含量はバナドモリ ブデン酸比色法（安田，1996）打よび Fe 含量はフェナント ロリン法（JIS K0102）を用いて測定した．各元素とも植物 体乾物 $100 \mathrm{~g}$ 中の含有量として算出した.

\section{3. 統計分析}

実験データは平均值と標準誤差で表し, 統計解析は Turkey-Kramer 法を用いて有意検定を行い，P 值が 0.05 以 下の時に統計的に有意差があるとした.

\section{結果および考察}

夜温の違いが最大葉長, 総花数, 雌花数打よび雌花率に 及ぼす影響を第 1 表に示した。最大葉長は，夜温処理開始 後から温度処理期間中，全処理区間で有意差はなく同水準 の伸長を示したことから，最大葉長に対する夜温の影響は 少ないことが窥われた。総花数は，中夜温区では温度処理 22 日以降に低夜温区に比べ, 高夜温区では温度処理 8 日以 降に他の 2 処理区に比べて増加する傾向を示し，処理終了 時には高夜温区で 50.3 花, 中夜温区で 40.7 花抒よび夜温区 で 33.8 花となり，夜温の上昇とともに増加することが判明 した．平間ら（2006）は，ズッキーニと同科のキュウリは 夜温を上昇させると主茎の草丈が高くなることを報告し， また Hikosakaら（2008）は，昼温／夜温をそれぞれ高温区 $30 / 25^{\circ} \mathrm{C}$ 打よび低温区 $23 / 17^{\circ} \mathrm{C}$ 亿設定してキュウりを 栽培したところ，高温区は低温区に比べより多くの節が発 達したと述べている．このことから，ズッキーニの花は各 節の葉腋に着生するため，夜温が高まるにつれて主菱の節 数が増加し, 総花数の増加に繋がったと考兄られる.

雌花数は，処理終了時の低夜温区で 16.7 花，中夜温区で 17.8 花および高夜温区で 17.5 花と, 全処理区間で有意な差 は認められなかった。

雌花率は, 特に温度処理 29 日以降の高夜温区が, 他の処 理区に比べ有意に低下し, 処理終了時では低夜温区で49\%, 中夜温区で $44 \%$ 扎よび高夜温区で $35 \%$ となった. 高夜温区 の雌花率の低下は, 夜温処理による雌花数に変動がなかっ たため, 処理温度の上昇に伴い花芽が着生する葉腋は増加 したものの，雄花が着生する率が高かったためと考兄られ る. キュウリやカボチャでは, 低温で雌花形成が促進され ることが報告（Cantliffe, 1981; Wien ら，2004）されている 
第 1 表 各夜温処理が最大葉長, 総花数, 雌花数および雌花率に及ぼす影響

\begin{tabular}{|c|c|c|c|c|c|c|c|c|}
\hline & & \multicolumn{7}{|c|}{ 温度処理後日数（平均值 \pm 標準誤差） } \\
\hline & & 1 日 & 8 日 & 15 日 & 22 日 & 29 日 & 36 日 & 43 日 \\
\hline \multirow{3}{*}{$\begin{array}{c}\text { 最大葉長 } \\
\quad(\mathrm{cm})\end{array}$} & 低夜温区 & $22.2 \pm 0.5 \mathrm{a}^{\mathrm{z}}$ & $30.3 \pm 0.2 \mathrm{a}$ & $44.5 \pm 0.5 \mathrm{a}$ & $57.8 \pm 0.6 \mathrm{a}$ & $70.7 \pm 0.7 \mathrm{a}$ & $79.7 \pm 0.8 \mathrm{a}$ & $84.8 \pm 1.0 \mathrm{a}$ \\
\hline & 中夜温区 & $21.5 \pm 0.4 \mathrm{a}$ & $31.5 \pm 0.6 \mathrm{a}$ & $49.3 \pm 0.5 \mathrm{a}$ & $61.3 \pm 0.6 \mathrm{a}$ & $75.5 \pm 0.7 \mathrm{a}$ & $83.7 \pm 1.3 \mathrm{a}$ & $86.2 \pm 1.4 \mathrm{a}$ \\
\hline & 高夜温区 & $22.5 \pm 0.3 \mathrm{a}$ & $33.3 \pm 0.4 \mathrm{a}$ & $50.2 \pm 0.5 \mathrm{a}$ & $61.8 \pm 0.8 \mathrm{a}$ & $76.7 \pm 1.0 \mathrm{a}$ & $84.0 \pm 1.6 \mathrm{a}$ & $86.3 \pm 1.5 \mathrm{a}$ \\
\hline \multirow{3}{*}{$\begin{array}{l}\text { 総花数 } \\
\text { (花) }\end{array}$} & 低夜温区 & $4.0 \pm 0.0 \mathrm{a}$ & $7.8 \pm 0.2 \mathrm{a}$ & $12.0 \pm 0.0 \mathrm{a}$ & $16.7 \pm 0.3 \mathrm{a}$ & $23.2 \pm 0.2 \mathrm{a}$ & $28.7 \pm 0.2 \mathrm{a}$ & $33.8 \pm 0.3 \mathrm{a}$ \\
\hline & 中夜温区 & $4.0 \pm 0.0 \mathrm{a}$ & $9.0 \pm 0.0 \mathrm{a}$ & $13.2 \pm 0.2 \mathrm{a}$ & $19.8 \pm 0.2 \mathrm{a}$ & $27.7 \pm 0.2 b$ & $34.2 \pm 0.2 b$ & $40.7 \pm 0.3 b$ \\
\hline & 高夜温区 & $4.0 \pm 0.0 \mathrm{a}$ & $10.0 \pm 0.0 \mathrm{a}$ & $16.3 \pm 0.3 a$ & $24.3 \pm 0.2 b$ & $33.5 \pm 0.4 \mathrm{c}$ & $42.0 \pm 0.5 \mathrm{c}$ & $50.3 \pm 0.7 \mathrm{c}$ \\
\hline \multirow{3}{*}{$\begin{array}{c}\text { 雌花数 } \\
\text { (花) }\end{array}$} & 低夜温区 & $0.0 \pm 0.0 \mathrm{a}$ & $0.0 \pm 0.0 \mathrm{a}$ & $1.5 \pm 0.3 \mathrm{a}$ & $4.3 \pm 0.4 a$ & $7.8 \pm 0.5 \mathrm{a}$ & $12.3 \pm 0.5 \mathrm{a}$ & $16.7 \pm 0.7 \mathrm{a}$ \\
\hline & 中夜温区 & $0.0 \pm 0.0 \mathrm{a}$ & $0.0 \pm 0.0 \mathrm{a}$ & $1.7 \pm 0.3 \mathrm{a}$ & $4.7 \pm 0.5 \mathrm{a}$ & $9.5 \pm 0.8 \mathrm{a}$ & $13.8 \pm 0.9 \mathrm{a}$ & $17.8 \pm 1.6 \mathrm{a}$ \\
\hline & 高夜温区 & $0.0 \pm 0.0 \mathrm{a}$ & $0.2 \pm 0.2 \mathrm{a}$ & $2.7 \pm 0.2 \mathrm{a}$ & $5.5 \pm 0.2 \mathrm{a}$ & $9.5 \pm 0.7 \mathrm{a}$ & $13.0 \pm 0.5 \mathrm{a}$ & $17.5 \pm 0.5 \mathrm{a}$ \\
\hline \multirow{3}{*}{$\begin{array}{c}\text { 雌花率 } \\
(\%)^{y}\end{array}$} & 低夜温区 & $0.0 \pm 0.0 \mathrm{a}$ & $0.0 \pm 0.0 \mathrm{a}$ & $12.5 \pm 2.6 \mathrm{a}$ & $26.0 \pm 2.1 \mathrm{a}$ & $33.8 \pm 2.2 \mathrm{a}$ & $43.0 \pm 1.8 \mathrm{a}$ & $49.3 \pm 2.2 \mathrm{a}$ \\
\hline & 中夜温区 & $0.0 \pm 0.0 \mathrm{a}$ & $0.0 \pm 0.0 \mathrm{a}$ & $12.7 \pm 2.3 \mathrm{a}$ & $23.5 \pm 2.5 \mathrm{a}$ & $34.3 \pm 2.5 \mathrm{a}$ & $40.5 \pm 2.6 \mathrm{a}$ & $43.9 \pm 3.8 \mathrm{a}$ \\
\hline & 高夜温区 & $0.0 \pm 0.0 \mathrm{a}$ & $1.7 \pm 1.5 \mathrm{a}$ & $16.3 \pm 1.2 \mathrm{a}$ & $22.6 \pm 0.7 \mathrm{a}$ & $28.4 \pm 1.3 b$ & $31.0 \pm 1.3 b$ & $34.8 \pm 1.3 b$ \\
\hline
\end{tabular}

$\mathrm{z}$ 異なる英小文字は，温度処理区間で Tukey-Kramer 法により $\mathrm{P}<0.05$ で有意差有り（n=10）

$\mathrm{y}$ 雌花率 $=$ 雌花数 $/$ 総花数 $\times 100$

が，本研究に拉いて，雌花率が低夜温区と中夜温区で差が なく，高夜温区で低下したことから，ズッキーニでは低夜 温で雌花形成が促進されるのではなく, 高夜温で雌花形成 が抑制されるものと推察される。

夜温の違いによる雌花の開花率と着果率に及ぼす影響を 第 1 図に示した. 開花率は, 低夜温区で $88.66 \%$, 中夜温区 で 72.39\%，高夜温区では $0 \%$ と雌花の開花が確認されず, 夜温が高くなるにつれ低下することが判明した．杉山ら （1962）は，開花前のキュウリの雄花に高温処理を与兄ると 開花不全が起こること, Wien ら（2004）はカボチャでは高 温条件下（昼温 $32^{\circ} \mathrm{C} /$ 夜温 $27^{\circ} \mathrm{C}$ ) で雌花の形成拈よび開 花が遅延することを報告した。 また，Penarandaら（2007） はズッキーニの未開雌花は雄ずいが退化できず，両性化に なり開花できなくなると述べている。 これらから，高夜温 区での不着果は, 雌花の開花不全によると推測される.

夜温の違いによる着果率は, 高夜温区で $0 \%$ となり, 低夜 温区で $31.43 \%$ 打よび中夜温区で $39.76 \%$ となった(第 1 図).

中夜温区の開花率は低夜温区よりも減少したものの，昼 夜温区の着果率は低夜温区ょりも若干の上昇傾向を示し た. ズッキーニと同科のメロンに扔いては, 昼温 $30^{\circ} \mathrm{C} /$ 夜温 $25^{\circ} \mathrm{C}$ よりも昼温 $30^{\circ} \mathrm{C} /$ 夜温 $15^{\circ} \mathrm{C}$ で雌花の着生節が 低位となり, 夜温の温度が上昇するにつれ, 雌花の着生節 位が高まり，さらに節位が高まるについて開花しにくくな ることが明らかになっている（木下・益田，1975）。このこ とから, 実験終了時の全処理区の雌花数は同程度であった が，低夜温区で雌花の着生節位が低下し，低位の雌花数が 増加して開花したことによって, 低夜温区で開花率が若干 高くなったと推察される. しかしながら, 中夜温区の着果 率が若干高くなったのは, カボチャの花粉が最高発芽力を 発揮する温度が $20 \sim 25^{\circ} \mathrm{C}$ であるため（糠谷, 2007）, 受 粉が正常に行わ机, 果実肥大も正常に行われたためと考兄 られた。
次に, 昼温の違いが最大葉長, 総花数, 雌花数および雌 花率に及ぼす影響を第 2 表に示した。最大葉長は，温度処 理終了時の低昼温区で $70.4 \mathrm{~cm}$, 中昼温区で $72.6 \mathrm{~cm}$ おちよび 高昼温区で $65.0 \mathrm{~cm}$ と高昼温区で最小であったものの，䚾 とんぞ差は認められなかった．各処理区の総花数は，高昼 温区が 31.4 花打よび中昼温区が 30.8 花となり, 低昼温区の 26.6 花に比べ有意に多かった．雌花数揖よび雌花率は，全 処理区間で有意差は認められなかったが，中昼温区で雌花 数が増加する傾向と高昼温区で雌花率が減少する傾向が認 められた。な拝，昼温処理に扔ける開花率および着果率は データとして示していないが，昼温を変動させても開花率 および着果率に大きな変動はないことが観察された。

Grimstad・Frimanslund（1993）は，キュウリの花芽形成 は夜温 $15 \sim 27^{\circ} \mathrm{C}$ の範囲で誘導が促進されるが，昼温の上 昇に伴い減少すると述べている。このことから，高昼温区で も雌花形成が若干抑制された可能性がある. 雌花率が高夜温 区で有意に減少したのに対し, 昼温区で有意差が認められな かったことから, ズッキー二の雌花形成に打兴温度の影響 は昼温に比へ, 夜温が強く雌花形成に影響を与兄, 特に夜温 $30^{\circ} \mathrm{C}$ が雌花形成を著しく抑制することが示唆された.

夜温の違いによる主要無機成分 $\mathrm{N}, \mathrm{K} ， \mathrm{P}, \mathrm{Ca}, \mathrm{Mg}$ 打よ び $\mathrm{Fe}$ 含量に及ぼす影響を第 3 表に示した. 植物体 $100 \mathrm{gDW}$ 中に含まれる $\mathrm{N} ， \mathrm{~K} ， \mathrm{P}$ 拈よび $\mathrm{Ca}$ 含有量は高夜温区が，中 夜温区拉よび低夜温区に比べ高くなる傾向を示したが, $\mathrm{Mg}$ および $\mathrm{Fe}$ 含有量は全処理区間で有意差は認められなかっ た.へチマ (Luffa cylindrical L.) において， N および Pが 雌性化を促進するとの報告（Omini・Hossain, 1987）がある が，ズッキーニに打いて $\mathrm{N}$ 和よび $\mathrm{P}$ の含有量が最も多かっ たのは, 雌花率が低かった高夜温区であったことから, ズッ キーニに打ける $\mathrm{N}$ 打よびPなどの主要無機成分は雌花形成 促進にはほとんど影響を及ぼさないこと，また，高夜温区 に打注開花不全による着果率の低下は，主要無機成分の 
第 2 表 各昼温処理が最大葉長, 総花数, 雌花数および雌花率に及ぼす影響

\begin{tabular}{|c|c|c|c|c|c|}
\hline & & \multicolumn{4}{|c|}{ 温度処理後日数（平均值 \pm 標準誤差） } \\
\hline & & 2 日 & 16 日 & 26 日 & 34 日 \\
\hline \multirow{3}{*}{$\begin{array}{c}\text { 最大葉長 } \\
(\mathrm{cm})\end{array}$} & 低昼温区 & $43.1 \pm 0.6 \mathrm{a}^{\mathrm{z}}$ & $59.6 \pm 0.3 \mathrm{a}$ & $66.4 \pm 1.0 \mathrm{a}$ & $70.4 \pm 1.0 \mathrm{a}$ \\
\hline & 中昼温区 & $47.0 \pm 0.4 \mathrm{a}$ & $64.8 \pm 0.4 \mathrm{a}$ & $69.4 \pm 1.2 \mathrm{a}$ & $72.6 \pm 1.5 \mathrm{a}$ \\
\hline & 高昼温区 & $46.1 \pm 0.2 \mathrm{a}$ & $57.2 \pm 0.7 \mathrm{a}$ & $62.4 \pm 0.8 \mathrm{a}$ & $65.0 \pm 1.7 \mathrm{a}$ \\
\hline \multirow{3}{*}{$\begin{array}{c}\text { 総花数 } \\
\text { (花) }\end{array}$} & 低昼温区 & $11.0 \pm 0.0 \mathrm{a}$ & $16.4 \pm 0.2 \mathrm{a}$ & $19.2 \pm 0.3 \mathrm{a}$ & $26.6 \pm 0.4 \mathrm{a}$ \\
\hline & 中昼温区 & $12.0 \pm 0.0 \mathrm{a}$ & $18.0 \pm 0.0 \mathrm{a}$ & $22.0 \pm 0.3 \mathrm{a}$ & $30.8 \pm 0.3 b$ \\
\hline & 高昼温区 & $12.2 \pm 0.0 \mathrm{a}$ & $19.0 \pm 0.2 \mathrm{a}$ & $23.6 \pm 0.5 \mathrm{a}$ & $31.4 \pm 0.6 \mathrm{~b}$ \\
\hline \multirow{3}{*}{$\begin{array}{c}\text { 雌花数 } \\
\text { (花) }\end{array}$} & 低昼温区 & $1.4 \pm 0.0 \mathrm{a}$ & $3.2 \pm 0.0 \mathrm{a}$ & $7.4 \pm 0.2 \mathrm{a}$ & $14.0 \pm 0.2 \mathrm{a}$ \\
\hline & 中昼温区 & $1.6 \pm 0.0 \mathrm{a}$ & $4.6 \pm 0.0 \mathrm{a}$ & $8.0 \pm 0.4 \mathrm{a}$ & $17.0 \pm 0.4 \mathrm{a}$ \\
\hline & 高昼温区 & $1.2 \pm 0.0 \mathrm{a}$ & $5.8 \pm 0.0 \mathrm{a}$ & $8.6 \pm 0.4 \mathrm{a}$ & $13.4 \pm 0.3 \mathrm{a}$ \\
\hline \multirow{3}{*}{$\begin{array}{c}\text { 雌花率 } \\
(\%)^{\mathrm{y}}\end{array}$} & 低昼温区 & $12.7 \pm 0.0 \mathrm{a}$ & $19.5 \pm 0.0 \mathrm{a}$ & $38.5 \pm 1.7 \mathrm{a}$ & $52.6 \pm 0.8 \mathrm{a}$ \\
\hline & 中昼温区 & $13.3 \pm 0.0 \mathrm{a}$ & $25.6 \pm 0.0 \mathrm{a}$ & $36.4 \pm 3.2 \mathrm{a}$ & $55.2 \pm 1.9 \mathrm{a}$ \\
\hline & 高昼温区 & $9.8 \pm 0.0 \mathrm{a}$ & $30.5 \pm 0.0 \mathrm{a}$ & $36.4 \pm 3.0 \mathrm{a}$ & $42.7 \pm 1.5 \mathrm{a}$ \\
\hline
\end{tabular}

$\mathrm{z}$ 異なる英小文字は，温度処理区間で Tukey-Kramer 法により $\mathrm{P}<0.05$ で有意差有り $(\mathrm{n}=10)$

$\mathrm{y}$ 雌花率 $=$ 雌花数 $/$ 総花数 $\times 100$

第 3 表 各夜温処理が主要無機 6 成分含量に及ぼす影響

\begin{tabular}{ccccccc}
\hline \hline & \multicolumn{5}{c}{ 含量 $\left(\mathrm{g} \cdot 100 \mathrm{~g}^{-1} \mathrm{DW} \pm\right.$ 標準誤差 $)$} \\
\cline { 2 - 7 } & $\mathrm{N}$ & $\mathrm{K}$ & $\mathrm{P}$ & $\mathrm{Ca}$ & $\mathrm{Mg}$ & $\mathrm{Fe}$ \\
\hline 低夜温区 & $5.0 \pm 0.1 \mathrm{a}^{\mathrm{z}}$ & $6.8 \pm 0.3 \mathrm{a}$ & $0.5 \pm 0.0 \mathrm{a}$ & $0.2 \pm 0.0 \mathrm{a}$ & $0.4 \pm 0.0 \mathrm{a}$ & $0.4 \pm 0.1 \mathrm{a}$ \\
中夜温区 & $5.2 \pm 0.2 \mathrm{a}$ & $7.5 \pm 0.2 \mathrm{a}$ & $0.6 \pm 0.0 \mathrm{a}$ & $0.1 \pm 0.0 \mathrm{a}$ & $0.4 \pm 0.0 \mathrm{a}$ & $0.4 \pm 0.0 \mathrm{a}$ \\
高夜温区 & $5.6 \pm 0.0 \mathrm{~b}$ & $8.4 \pm 0.1 \mathrm{~b}$ & $0.7 \pm 0.0 \mathrm{~b}$ & $0.3 \pm 0.0 \mathrm{~b}$ & $0.4 \pm 0.0 \mathrm{a}$ & $0.5 \pm 0.0 \mathrm{a}$ \\
\hline
\end{tabular}

$\mathrm{z}$ 異なる英小文字は，温度処理区間で Tukey-Kramer 法により $\mathrm{P}<0.05$ で有意差有り $(\mathrm{n}=10)$

欠乏や過㮃によるものではないことなどが窥われた。

以上より，ズッキー二の雌花形成には，昼温ではなく夜 温が強く影響し, 最適な夜温は $20^{\circ} \mathrm{C}$ 前後が適していると 判断された. 特に, 夜温 $30^{\circ} \mathrm{C}$ で雌花形成を抑制すること が明らかとなった．今後さらに，ズッキー二の収穫量安定 に向けた雌花の開花执よび着果と栽培温度, 特に夜温との 関連性を詳細に検討すべきである.

\section{摘 要}

栽培温度の違いがズッキー二の雌花形成に及ぼす影響 を，自然光型人工気象装置を用いて調査した。夜温処理区 に扣ける最大葉長および此花数は, 全処理区で同水準の増 加を示し有意差はなかったが，総花数は夜温が上がるにつ れ増加した，その結果，雌花率は低夜温 $\left(10^{\circ} \mathrm{C}\right)$ 区および 中夜温区 $\left(20^{\circ} \mathrm{C}\right)$ に比べて高夜温区 $\left(30^{\circ} \mathrm{C}\right)$ で有意に低下 し, 低・中夜温区ではほとんど差はなかった。開花率は低 夜温区で最も高く，続いて中夜温区となり，高夜温区では 全く開花しなかった。着果率は低夜温区打よび中夜温区で は有意な差でなかったものの, 中夜温で高まる傾向を示し た．高夜温区では雌花の開花が認められず，着果率は $0 \%$ であった，昼温処理区に拈ける最大葉長は，低 $\left(20^{\circ} \mathrm{C}\right)$ 抒 よび中昼温区 $\left(25^{\circ} \mathrm{C}\right)$ に比べて高昼温区 $\left(35^{\circ} \mathrm{C}\right)$ で短く なった，総花数は，中昼温区および高昼温区で有意に増加 したが, 雌花数および雌花率は全処理区間で有意差は認め
られなかった。これらの結果から，ズッキーニの雌花形成 に及ぼす栽培温度の影響は, 夜温 $30^{\circ} \mathrm{C}$ では雌花率の低下 と雌花の開花を著しく抑制すること，㡺温は雌花形成に大 きな影響を与えないことが判明した。

\section{引用文献}

Cantliffe, D. J. 1981. Alteration of sex expression in cucumber due to changes in temperature, light intensity and photoperiod. J. Amer. Soc. Hort. Sci. 106: 133-136.

Grimstad, S. O. and E. Frimasnalund. 1993. Effects of different day and night temperature regimes on greenhouse cucumber young plant production, flower bud formation and early yield. Sci. Hortic. 53: 191-204.

Haim, N., C. Ron, E. Menahan and B. Yosef. 1989. PaclobutrazolA plant growth retardant for increasing yield fruit quality in muskmelon. J. Amer. Soc. Hort. Sci. 114: 762-766.

早田保義. 1988. メロン着果および発育に及ぼす 6-Benzylaminopurin (BA) の影響. 広島農業短大研報. 8: 475-478.

早田保義・新美善行・牧田勝紘・磯田竜三. 1990. メロン 果実の着果拉よび糖蓄積に及ぼすサイトカイニンの影 響. 園学雑. 59 (別 1)：370-371.

Hikosaka, S., P. Boonkorkaew and N. Sugiyama. 2008. Effect of air temperature at the seedling stage and pollination on the development of pistillate flowers and fruit set in cucumbers. 
Environ. Control Biol. 46: 249-256.

平間信夫・水澤秀雅 - 小豆畑二美夫・松浦誠司. 2006. 八 ウス促成栽培に扣ける着果前の夜温管理の違いがキュ ウリの生育および収穫本数に及ぼす影響. 園学雑. 75 (別 1) : 166.

木下恵介・益田忠雄. 1975. 八ネー・デューメロンの雌花 着生に及ぼす温度の影響. 岡山大農学報. 46: 24-28.

Li, X. X., J. Yasukawa and Y. Hayata. 2005. Role of endogenous indole-3-acetic acid in fruit set of zucchini. J. Japan. Soc. Hort. Sci. 74: 167-169.

永原太郎・岩尾裕之・久保彰治. 1964. 全訂食品分析法. p. 153 . 柴田書店. 東京.

糠谷 明. 2007. ウリ科野菜. p. 50. 金浜耕基編著. 野菜 園芸学. 文永堂出版. 東京.

Omini, M. E. and M. G. Hossain. 1987. Modification of sex expression in sponge gourd (Luffa cylindrica L.) Roem by mineral nutrient treatments. Genetica 74: 203-209.

Papadopoulou, E. and R. Grumet. 2005. Brassinosteriod-induced femaleness in cucumber and relationship to ethylene production. HortScience 40: 1763-1767.

Penaranda, A., M. C. Payan, D. Garrido, P. Gomez and M. Jamilena. 2007. Production of fruits with attached flowers in zucchini squash is correlated with the arrest of maturation of female flower. J. Hort. Sci. Biotech. 82: 579-584.

嶋田典司. 2003. 全窒素. p. 94-104. 土㙋標準分析測定法 委員会編著. 土堙標準分析・測定法. 博友社. 東京.

杉山直儀・高橋和彦・岩堀修一. 1962. 果菜類の高温障害. 園学雑. 31: 141-145.

田口多喜子・檜森靖則・田村 晃. 2004. 地温上昇抑制に よるズッキーニの障害果軽減技術. 東北農業研究. 57 : 213-214.

Takahashi, H., T. Saito and H. Suge. 1983. Separation of effect of photoperiod and hormones on sex expression in cucumber. Plant Cell Physiol. 24: 147-154.

Wien, H. C., S. C. Stapleton, D. N. Maynard, C. M. Clurg and D. Riggs. 2004. HortScience 39: 239-242.

安田明美. 1996. 無機成分. p. 258-259. 新・食品分析法編 集委員会編著. 新・食品分析法. 光琳. 東京. 